\title{
The impact of climatic factors on the relative chloronhvll content and yield of a maize hybrid in a long-term experiment
}

\author{
Éva Horváth - Péter Fejér - Adrienn Széles \\ University of Debrecen, Faculty of Agricultural and Food Sciences and Environmental Management, \\ Institute for Land Utilisation, Technology and Regional Development, Debrecen \\ horvath.eva@agr.unideb.hu
}

\begin{abstract}
SUMMARY
The impact of the climatic factors of crop year on the relative chlorophyll content of maize was examined for three years. The examinations were carried out on the Látókép Experiment Site of the University of Debrecen on calcareous chernozem soil in a small-plot, non-irrigated long-term field experiment with strip plot design. In addition to a non-fertilised (control) treatment, nitrogen ( $N$ ) fertiliser doses were applied as base and top dressing. The 60 and $120 \mathrm{~kg} \mathrm{~N} \mathrm{ha-1} \mathrm{base} \mathrm{dressing} \mathrm{doses} \mathrm{were} \mathrm{followed} \mathrm{by} \mathrm{two} \mathrm{top} \mathrm{dressing} \mathrm{doses} \mathrm{at} \mathrm{the} \mathrm{V6} \mathrm{and} \mathrm{V12} \mathrm{phenophases.}$ Averaged over the different fertiliser treatments, SPAD readings increased in all three years as the growing season progressed. The highes SPAD value increase was observed in the average crop year (2017) at the V12 phenophase (11.8), which further increased at the R1 phenophas, by 3,7. No significant Spad value difference was observed between the average (2017) and the dry year (2018) at the V6 growth phase. However, in the wet crop year (2016), the V6 $6_{90}$ treatment provided the statistically highest relative chlorophyll content (46.8). At the V12 phenophase, the base dressing dose of $120 \mathrm{~kg} \mathrm{~N} \mathrm{ha}^{-1}+30 \mathrm{~kg} \mathrm{~N} \mathrm{ha}^{-1}\left(\mathrm{V6}_{150}\right)$ showed to be successful in two years (2016 and 2018$)$, while in 2017, the base dressing dose of $A_{60}$ was successful. The impact of crop year on relative chlorophyll content can be clearly shown at the R1 growth stage. In all three years, the significantly highest relative chlorophyll content could be achieved at different nutrient levels: $A_{60}$ in 2016 , V6 $6_{150}$ in 2017 and $V 6_{90}$

In a wet year (2016), higher yield could be achieved as a result of the $60 \mathrm{~kg} \mathrm{~N} \mathrm{ha-1}$ base dressing and $30 \mathrm{~kg} \mathrm{~N} \mathrm{ha}^{-1}$ at the V6 growth stage (V6 90$)$ as top dressing in comparison with 2017 and 2018, when higher fertiliser dose $1120 \mathrm{~kg} \mathrm{~N} \mathrm{ha}^{-1}$ base dressing and $30 \mathrm{~kg} N$ ha ${ }^{-1}$ top dressing at the V6 growth stage) was needed to achieve a significant yield surplus.

Altogether, averaged over the different treatments, the highest yield (12.48 tha $\left.{ }^{-1}\right)$ was observed in the wet year, when the relative chlorophyll content was also the highest (50.6).
\end{abstract}

Keywords: climate change, maize, relative chlorophyll content, yield, nitrogen

\section{INTRODUCTION}

Currently, maize is one of the most significant culture crops of the world. In 1990, the global maize production was 484 million tons, which increased to 1.060 million tons by 2016 (FAOSTAT, 2018). The increase of maize production is the most dynamic among the different cereals. Due to its fundamental role in feeding the world's population and the rapid increase of its production, maize has become one of the most important culture crops of the world (Nagy, 2008).

Within the European Union, Hungary has an outstanding position concerning maize production, with a sowing area between 1-1.2 million hectares (Nagy, 2018). Maize has a 26.1\% ratio of the sown area in Hungary. Averaged over the twenty years between 1998-2017, the sowing area of maize was 1.110 million hectares, with the extremes being 2017 (drought - 988 million hectares) and 2011 (1.285 million hectares). In the same period, the average yield of maize was 6.1 $\mathrm{t} \mathrm{ha}^{-1}$, with the extremes being 2007 (3.7 $\left.\mathrm{t} \mathrm{ha}^{-1}\right)$ and $2016\left(8.6 \mathrm{t} \mathrm{ha}^{-1}\right)$ (HCSO, 2018)

Climate change significantly affects yield safety and maize yield is going to decrease in the next 20 years (Mukesh et al., 2017). In order to overcome this problem, it is important to choose the proper hybrids, which greatly determine yield and quality (Izsáki, 2006; Győri, 2010; Pepó, 2017). In addition, the increased water need of the crop due to climate change may also result in yield decrease, which can be eliminated by choosing stress-tolerant maize hybrids that can endure high temperatures (Islam et al., 2012; Marton et al., 2012; Jolánkai et al., 2016).

As in the case of all crops, proper nutrient replenishment is indispensable also for maize. Fertilisation has a positive effect on maize yield and it is significant in the uptake of both macro- and microelements (Berzsenyi and Lap, 2003; Csajbók, 2005; Ványiné Széles et al., 2012a; Árendás et al., 2014; Nagy, 2017; Seyyed et al., 2018). Nitrogen supply has the greatest role in obtaining high yields (Sárvári and Pepó, 2014; Graming et al., 2017; Széles et al., 2018b). The obtained findings showed that nitrogen applied on the spot and specifically in conformity with the differences between hybrids could increase maize yield (Soil Science Society of America, 2007; Noha and Znag, 2012).

The 'greenness' of maize leaf depends on the chlorophyll content of the crop, which is affected by various factors (Ványiné Széles and Nagy, 2012). Schepers et al. (1992) showed a close correlation between relative chlorophyll content (SPAD readings) and the $\mathrm{N}$ supply level of the crop, similarly to several other researchers who came to the same conclusion (Evans, 1989; Niinemets and Tenhunen, 1997; Berzsenyi et al., 2006). Consequently, nitrogen in the maize leaf is incorporated for example into chlorophylls (Rasmus et al., 2009). A significant increase of relative chlorophyll content (SPAD readings) and the vegetation index (NDVI) can be observed at the R1 phenophase as a result of applying $90 \mathrm{~kg} \mathrm{ha}^{-1}$ nitrogen (Kesi and Pawel, 2012). The 
relative chlorophyll content measured at the $\mathrm{R} 1$ growth stage gives a reliable prediction of yield and protein content, but the strength of this correlation is different for each hybrid and crop year (Ványiné Széles et al., 2012b)

\section{MATERIALS AND METHODS}

Production site description: Our examinations were performed at the Látókép Experiment Site of the University of Debrecen, Hungary ( $47^{\circ} 33^{\prime} \mathrm{N}, 21^{\circ} 26^{\prime}$ E, $111 \mathrm{~m}$ asl), on calcareous chernozem soil formed on loess. The small-plot long-term field experiment had a strip plot design. Measurements were performed under natural precipitation supply conditions on the maize hybrid Renfor (FAO 320) in 2016, 2017 and 2018.

Soil. Based on the soil analysis results of 2012, the average $\mathrm{pHKCl}$ value of the soil was 6.6 , i.e. slightly acidic, which is optimal from the aspect of the nutrient uptake of crops. The Arany plasticity index was 39 in the upper $(20 \mathrm{~cm})$ layer of the soil and the total amount of water-soluble salts was $0.04 \%$, i.e. low salt content. The carbonic chalk content was around $0 \%$ in the upper $80 \mathrm{~cm}$ layer of the soil, i.e. the soil is chalk-deficient, but the chalk content increases to $12 \%$ from a depth of $100 \mathrm{~cm}$; therefore, the soil is moderately chalky. The organic matter content is $2.3 \%$ in the upper $20 \mathrm{~cm}$ layer. This value does not exceed $1.0 \%$ at the $120 \mathrm{~cm}$ depth of the soil. The potassium supply of the soil is adequate, while its $P$ supply can be considered average.

Experimental details. In addition to the nonfertilised (control) treatment, $\mathrm{N}$ fertiliser doses were applied as base and top dressing. The 60 and $120 \mathrm{~kg} \mathrm{~N}$ $\mathrm{ha}^{-1}$ base dressing doses were followed by two top dressing doses at the V6 and V12 phenophases (+30 and $+30 \mathrm{~kg} \mathrm{~N} \mathrm{ha}^{-1}$ ). The previous years the crop was maize. Maize was sown on 19/04/2016, 26/04/2017 and $23 / 04 / 2018$. Harvesting was performed on 14/10/2016, $12 / 10 / 2017$ and 23/04/2018. The amount of harvested grain yield was corrected to $14 \%$ moisture content.

Climatic characterisation of crop years. Weather was evaluated based on the data measured and logged by the weather station installed at the experiment site. The obtained results were compared to the means of the period between 1985-2015 (30-year average).

The growing season of 2016 was rich in precipitation. The sum of precipitation was $450 \mathrm{~mm}$, which was $110 \mathrm{~mm}$ higher than the 30-year average $(340 \mathrm{~mm})$. April was dry as there was less than $15 \mathrm{~mm}$ rain, which was well below the multiple-year average of $45 \mathrm{~mm}$. There was $69 \mathrm{~mm}$ rain in May, which was $17 \%$ higher than the average. The amount of rainfall was $146 \mathrm{~mm}$ in June, which was twice as high as the average amount of precipitation $(69 \mathrm{~mm})$ and one third of this amount arrived in only one day. July, August and September were rainy. The amount of rainfall was more than $20 \%$ higher than the average in all three months. There were 48 rainy days during the growing season of 2016, with 40 days when it rained more than $10 \mathrm{~mm}$. The amount of rain was higher than $20 \mathrm{~mm}$ for five days and there were only three days with the amount of rain lower than $10 \mathrm{~mm}$. The month of sowing in 2016 was significantly warmer than the average $\left(+1.8^{\circ} \mathrm{C}\right)$, while May was $0.9^{\circ} \mathrm{C}$ colder. In June, the temperature was $1^{\circ} \mathrm{C}$ higher than the average, while July was average. In contrast, a temperature decrease was observed in August $\left(0.5^{\circ} \mathrm{C}\right)$, while September was warmer than the average (by $1.3^{\circ} \mathrm{C}$ ). 35 heat days were observed during the growing season.

In the first month of the growing season of 2018, the amount of rainfall was $18 \%$ higher than the average. However, there was a decrease in precipitation in May and June. The amount of rain was $11 \mathrm{~mm}$ higher in July, but $13 \mathrm{~mm}$ less in August in comparison with the average. Both months can be considered rainy. The temperature in July was average, but the monthly mean temperature was $1.8^{\circ} \mathrm{C}$ higher and the amount of precipitation was significantly lower than the average. However, there was nearly twice as much rain in September than the multiple-year average. $349 \mathrm{~mm}$ rain was observed during the growing season. The first three months were rainier than the average, while there was significantly less precipitation than the average during the other three months. At the beginning of the growing season, the temperature was lower than the average, however, in the critical month of June, it was $1.8^{\circ} \mathrm{C}$ higher. Altogether, the mean temperature of the growing season was similar to the average.

The growing season of 2018 was poor in precipitation. The total amount of rainfall was $311 \mathrm{~mm}$ during the growing season, which was lower than the average. There was $37 \mathrm{~mm}$ rain in the first month of the growing season. In the second half of May, $60 \mathrm{~mm}$ precipitation was observed in 7 days. There were 13 rainy days in June and $61 \mathrm{~mm}$ rain was observed during the month. August was the rainiest month with its 98 mm precipitation, which was $21 \%$ of the total amount. There was $13 \mathrm{~mm}$ precipitation in the month of harvesting, which was $27 \%$ lower than the average. The temperature of the growing season was $2.1^{\circ} \mathrm{C}$ higher than the average.

Statistical evaluation. A general linear model (GLM) was used to evaluate the correlation between the dependent variable (SPAD readings, yield) and the production factor (fertilisation, crop year). Duncan's test was used to compare yield and its mean values. Evaluation was performed using SPSS for Windows 21.0.

\section{RESULTS AND DISCUSSION}

\section{The effect of $\mathrm{N}$ fertilisation and phenophases on the relative chlorophyll content of maize}

The effect of fertilisation on SPAD readings was examined. Averaged over the three examined years, in accordance with the findings of Ványiné Széles (2008), Vig et al. (2010), Bónis et al. (2011) and Micskei et al. (2014), SPAD readings were affected by increasing fertiliser doses at a significance level of $0.1 \%$. A significant correlation was observed between phenological phases and fertilisation $(\mathrm{P}<0.001)$.

The effect of different treatments on the chlorophyll content of maize was examined with Duncan's test, which resulted in two homogeneous groups that 
significantly differed from each other $(\mathrm{P}<0.05)$ (Figure $1)$. The lowest SPAD reading was observed on the nonfertilised plot (41.6), from which the SPAD readings of all fertiliser doses differed. The highest SPAD reading was obtained in the case of the (V6_150) treatment (52.1). The lowest fertiliser dose (A_60) increased SPAD readings by $12.7 \%$. The difference between the base treatments of $\mathrm{A}_{60}$ and $\mathrm{A}_{120} \mathrm{~kg} \mathrm{~N}^{-1}$ was only $2.3 \%$. The $60 \mathrm{~kg} \mathrm{~N} \mathrm{ha}^{-1}$ base dressing was followed by $30 \mathrm{~kg} \mathrm{~N} \mathrm{ha}^{-1}$ in the $\mathrm{V} 6$ phenophase, resulting in a $3 \%$ increase in SPAD readings. The (V6_150) treatment showed an increase in SPAD readings by 3.1, which resulted in a $6.5 \%$ increase in comparison with the (A_120) treatment. The Duncan's test showed that the lowest SPAD reading (39.8) was obtained at the V6 growth stage, which significantly $(\mathrm{P}<0.05)$ differed from the SPAD reading measured at the V12 phenophase (48.2). The relative chlorophyll content further increased by the R1 growth stage (50.8), but this increase did not show any significant difference (Figure 2).

Figure 1: The effect of $\mathbf{N}$ fertiliser treatments on SPAD readings, averaged over the different phenological phases (Látókép, 2016-2018)

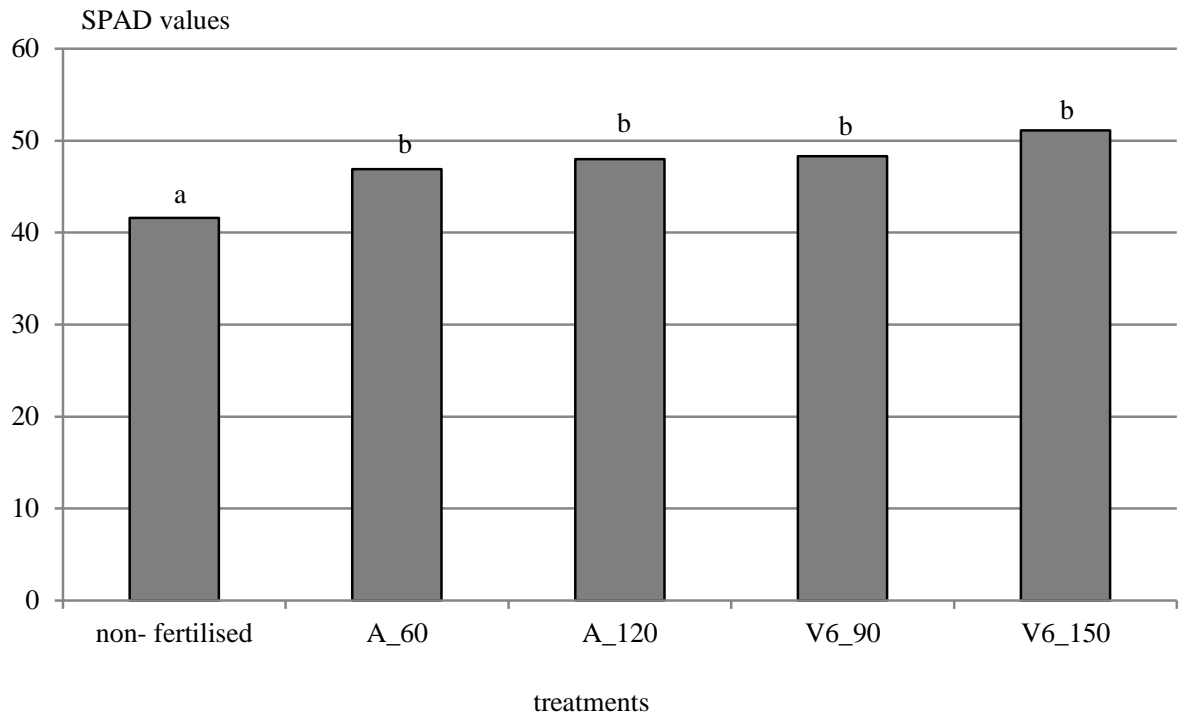

Note: based on the Duncan's test, yields marked with different letters significantly differ from each other at the probability levels of $\mathrm{P} \leq 0.05$

The impact of $\mathbf{N}$ fertilisation and phenological phases on the chlorophyll content of maize in different crop years

The effect of fertilisation on SPAD readings was observed in crop years with different precipitation supply. The obtained results were evaluated for each year (Table 1).

The lowest SPAD reading (46.0) was obtained at the V6 phenophase in the non-fertilised treatment in 2016 and there were no significant differences between the SPAD readings of fertilised plots. At the V12 growth stage, the base dressing of 60 and 120 $\mathrm{kg} \mathrm{N} \mathrm{ha}^{-1}$ increased SPAD readings, but the difference was not significant. The (A_60) base dressing was followed by a $30 \mathrm{~kg} \mathrm{ha}^{-1}$ dose in the V6 growth stage (V6_90), which did not result in a significant difference either. The highest SPAD reading (55.9) was obtained in the case of the (V6_150) treatment, i.e., the highest dose treatment of $120 \mathrm{~kg} \mathrm{~N} \mathrm{ha}^{-1}$ base dressing+30 kg N $\mathrm{ha}^{-1}$ top dressing treatment. Compared to the control treatment, only the $60 \mathrm{~kg} \mathrm{ha}^{-1}$ base dressing resulted in a significant increase of the SPAD readings at the R1 phenological phase.
Duncan's test was used to examine the effect of the fertiliser dose applied at the V6 growth stage in 2017, resulting in a single group of treatments. In this phenological phase, fertilisation did not have any relative chlorophyll increasing effect. At the V12 phenophase, the lowest SPAD reading was obtained in the non-fertilised treatment, from which all other fertilised treatments significantly differed. By applying the $60 \mathrm{~kg} \mathrm{~N} \mathrm{ha}^{-1}$ base dressing, the chlorophyll content of maize increased by 5.3. The highest SPAD reading (48.2) was obtained in the case of the (V6_150) treatment, which did not show any significant difference from the other fertiliser treatments. At the R1 phenophase, the Duncan's test resulted in three homogeneous groups. The SPAD reading of 39.7 of the non-fertilised treatment could be well distinguished from the other fertiliser treatments. The $60 \mathrm{~kg} \mathrm{~N} \mathrm{ha}^{-1}$ base dressing increased SPAD readings by 11.7 . No significant differences were observed between the (A_60), (A_120) and (V6_90) treatments. The (VE_150) treatment was shown to be the most effective and a significant increase in SPAD readings (by 6.3) was observed in comparison with the (A_120) treatment. 
Figure 2: The effect of phenophases on SPAD readings, averaged over the different fertiliser treatments (Látókép, 2016-2018)

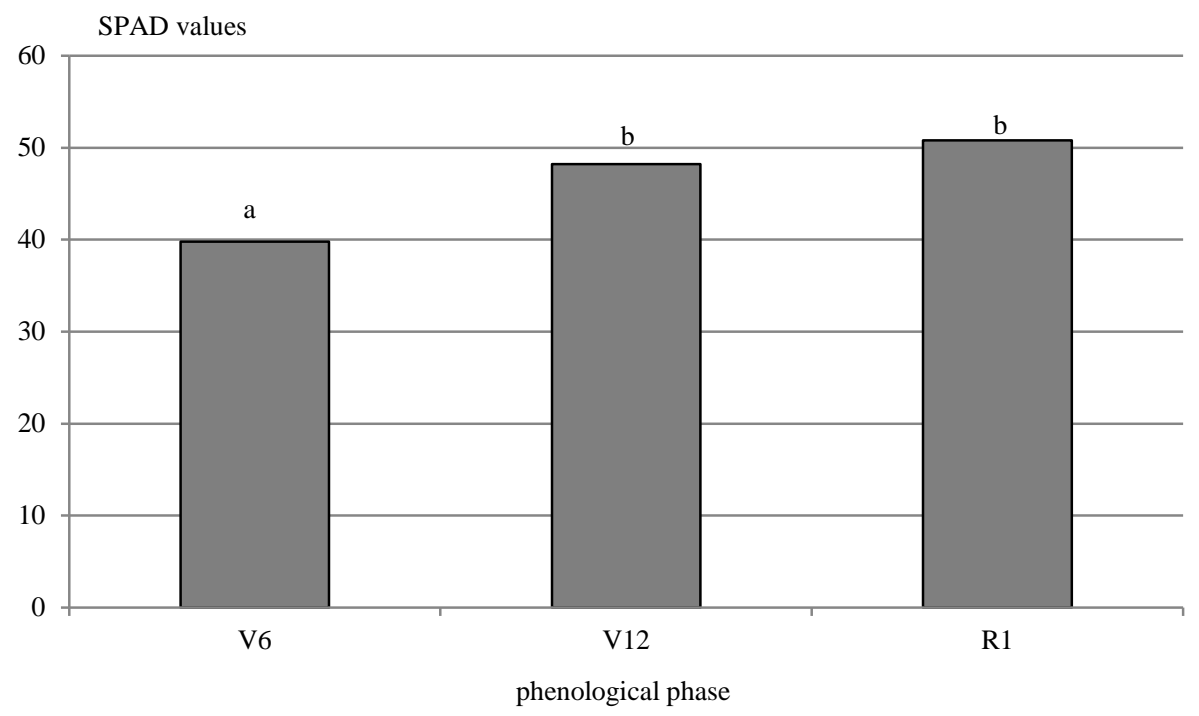

Note: based on the Duncan's test, yields marked with different letters significantly differ from each other at the probability levels of $\mathrm{P} \leq 0.05$

The effect of $\mathrm{N}$ fertilisation and phenophases on the chlorophyll content of maize (Látókép, 2016-2018)

\begin{tabular}{|c|c|c|c|c|c|c|c|c|c|}
\hline \multirow{2}{*}{$\begin{array}{l}\text { Fertiliser } \\
\text { treatments }\end{array}$} & \multicolumn{3}{|c|}{2016} & \multicolumn{3}{|c|}{2017} & \multicolumn{2}{|r|}{2018} & \\
\hline & V6 & V12 & $\mathrm{R} 1$ & V6 & V12 & R1 & V6 & V12 & $\mathrm{R} 1$ \\
\hline non-fertilised & $46.0 \mathrm{a}$ & $42.9 \mathrm{a}$ & $44.8 \mathrm{a}$ & $33.7 \mathrm{a}$ & $40.5 \mathrm{a}$ & $39.7 \mathrm{a}$ & $41.1 \mathrm{a}$ & $41.3 \mathrm{a}$ & $45.1 \mathrm{a}$ \\
\hline A_60 & $48.6 \mathrm{ab}$ & $51.3 \mathrm{ab}$ & $58.4 \mathrm{~b}$ & $33.0 \mathrm{a}$ & $45.8 \mathrm{~b}$ & $51.4 \mathrm{~b}$ & $40.1 \mathrm{a}$ & $47.1 \mathrm{ab}$ & $46.3 \mathrm{ab}$ \\
\hline A_120 & $50.1 \mathrm{ab}$ & $52.3 \mathrm{ab}$ & $59.4 \mathrm{~b}$ & $29.7 \mathrm{a}$ & $46.8 \mathrm{~b}$ & $51.6 \mathrm{~b}$ & $35.7 \mathrm{a}$ & $52.4 \mathrm{ab}$ & $54.2 \mathrm{ab}$ \\
\hline V6_90 & $46.8 \mathrm{~b}$ & $49.9 b$ & $56.7 \mathrm{~b}$ & $33.6 \mathrm{a}$ & $47.6 \mathrm{~b}$ & $51.5 \mathrm{~b}$ & $36.2 \mathrm{a}$ & $55.7 \mathrm{c}$ & $56.8 \mathrm{ab}$ \\
\hline V6_150 & $52.8 \mathrm{~b}$ & $55.9 \mathrm{c}$ & $61.0 \mathrm{~b}$ & $35.1 \mathrm{a}$ & $48.2 \mathrm{~b}$ & $57.9 \mathrm{c}$ & $33.9 \mathrm{a}$ & $59.6 \mathrm{ab}$ & $55.6 \mathrm{~b}$ \\
\hline
\end{tabular}

Note: based on the Duncan's test, yields marked with different letters significantly differ from each other at the probability levels of $\mathrm{P} \leq 0.05$

Due to the dry crop year of 2018, fertilisation had a SPAD reading decreasing effect at the V6 growth stage, in comparison with the non-fertilised treatment, but this decrease was not significant. At the V12 phenophase, the highest SPAD reading was obtained in the (V6_150) treatment (55.6), which resulted in a significant increase of 10.5 in comparison with the nonfertilised treatment, while there was no significant difference from the other fertiliser treatments. At the R1 growth stage, the most effective treatment was shown to be the (V6_90) treatment (55.7), showing a difference of 14.4 from the non-fertilised treatment and it significantly differed from the other fertiliser treatments.

The effect of crop year and $\mathbf{N}$ fertilisation on the relative chlorophyll content of maize in different phenological phases

$\mathrm{T}$ test was used to perform yearly comparison of the different fertiliser treatments. At the V6 phenophase, significant difference was observed between the rainy year of 2016 and the average crop year of 2017 in all treatments, except for (V6_150). The biggest difference was observed in the case of the base dressing of 120 $\mathrm{kg} \mathrm{N} \mathrm{ha}^{-1}$, as the SPAD readings decreased by 20.3 in 2017 ( $\mathrm{P}<0.01)$. Compared to the wet year (2016), a decrease in SPAD readings was shown in the dry crop year (2018), but this decrease is not significant in the case of the base dressing of $60 \mathrm{~kg} \mathrm{~N} \mathrm{ha}^{-1}$, followed by $30 \mathrm{~kg} \mathrm{~N} \mathrm{ha}{ }^{-1}$ in the $\mathrm{V}_{90}$ treatment. A significant difference was observed in the non-fertilised treatment, as well as the $\mathrm{A}_{120}$ and $\mathrm{V}_{150}$ treatments $(\mathrm{P}<0.05)$. Differences were observed between the SPAD readings of all treatments in both 2018 and 2017. In 2017, an increase in SPAD readings was shown. However, this difference was significant only in the non-fertilised treatment $(\mathrm{P}<0.01)$.

At the V_12 phenophase, compared to the wet year (2016), the relative chlorophyll content decreased in all treatments in the average crop year (2017), but this decrease was not significant. The observed difference was similar also between 2016 and 2018. In 2018, a decrease of SPAD readings was observed in all treatments, but this decrease was not significant. Compared to 2017, the relative chlorophyll content increased in 2018, but this increase was significant only in the non-fertilised treatment $(\mathrm{P}<0.05)$. 
At the R1 growth stage, the relative chlorophyll content decreased in all treatments in 2017, compared to 2016. However, significant differences were found only in the non-fertilised $(\mathrm{P}<0.05)$ and the $\left(\mathrm{A} \_120\right)$ treatments $(\mathrm{P}<0.05)$. None of the treatments showed significant differences between 2018 and 2016, as well as between 2018 and 2017 .

\section{The effect of $\mathbf{N}$ fertilisation on yield}

Considering the three examined years, yield decreased in he recent years (Figure 3) due to the small amount of rainfall and the higher mean temperature.

In the wet year of 2016, the yield of the nonfertilised treatment was $10.42 \mathrm{t} \mathrm{ha}^{-1}$. Compared to the non-fertilised treatment, similarly to the findings of Széles et al. (2018a), the $60 \mathrm{~kg} \mathrm{~N}^{-1}$ base dressing (A_60) significantly increased yield $(14.8 \%, \mathrm{P}<0.05)$. The $0.50 \mathrm{t} \mathrm{ha}^{-1}$ increase between the (A_60) and (A_120) base dressings was not significant. The base dressing treatment of $60 \mathrm{~kg} \mathrm{ha}^{-1}$ was followed by another $30 \mathrm{~kg} \mathrm{~N} \mathrm{ha}^{-1}$ at the $\mathrm{V} 6$ phenophase, resulting in a yield increase of $2.55 \mathrm{t} \mathrm{ha}^{-1}(\mathrm{P}<0.05)$. Yield increased as a result of the (V6_150) treatment $\left(2.60 \mathrm{t} \mathrm{ha}^{-1}\right.$; $\mathrm{P}<0.05)$ in comparison with the $120 \mathrm{~kg} \mathrm{~N}^{-1}$ base dressing treatment (A_120). The highest yield was provided by the (V6_150) treatment (15.10 t ha-1), but no significant difference was observed from the yield resulting from the (A_120) treatment.

In the average crop year of 2017 , the yield observed at the time of applying the $60 \mathrm{~kg} \mathrm{~N} \mathrm{ha}^{-1}$ base dressing treatment showed a $45.8 \%$ increase in comparison with the non-fertilised treatment $(\mathrm{P}<0.05)$. The difference in yield between the 60 and $120 \mathrm{~kg} \mathrm{~N} \mathrm{ha}^{-1}$ base dressings was not significant. Maize yield did not respond to the $60 \mathrm{~kg} \mathrm{~N} \mathrm{ha}^{-1}$ base dressing followed by $30 \mathrm{~kg} \mathrm{~N} \mathrm{ha}^{-1}$ at the V6 growth stage (V6_90) with a significant increase. Compared to the (A_120) base dressing, the top dressing (V6_150) applied at the V6 growth stage resulted in a significant difference of $23.6 \%$. The biggest significant yield increase was provided by the (V6_150) treatment.

The yield of the non-fertilised treatment was the lowest (7.20 tha $\left.\mathrm{ha}^{-1}\right)$ in the dry crop year (2018). The base dressing of $60 \mathrm{~kg} \mathrm{~N} \mathrm{ha}^{-1}$ resulted in a yield increase of $48 \%$. The difference between the (A_60) and (A_120) base dressings and the (A_60) and a further 30

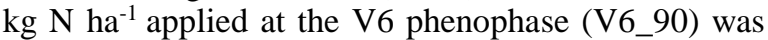
not significant. The (A_120) treatment followed by a further dose of $30 \mathrm{~kg} \mathrm{~N} \mathrm{ha}^{-1}\left(\mathrm{~V} 6 \_150\right)$ resulted in a yield surplus of $15.8 \%$.

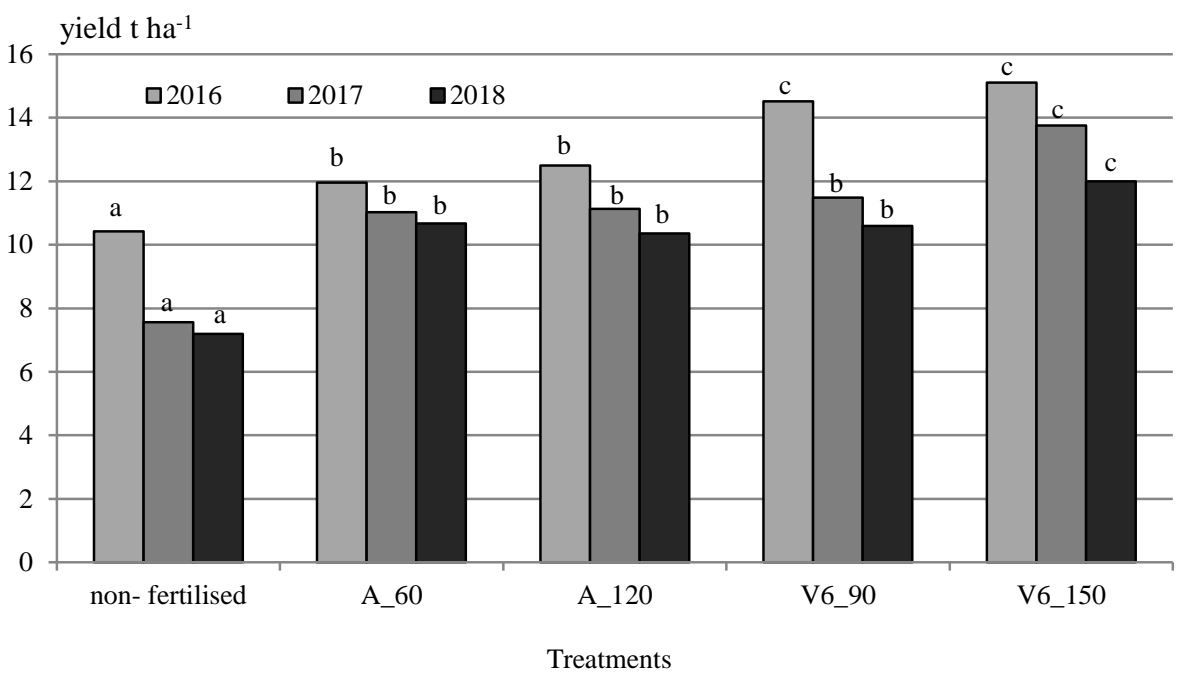

Note: based on the Duncan's test, yields marked with different letters significantly differ from each other at the probability levels of $\mathrm{P} \leq 0.05$

The effect of crop year and $\mathbf{N}$ fertilisation on yield

Comparing the yields of the wet (2016) and average crop year (2017), it can be concluded that the yield significantly decreased in all treatments in 2017, except for (A_60). The biggest significant difference was observed in the (V6_90) treatment (3.03 $\mathrm{t} \mathrm{ha}{ }^{-1}$, $\mathrm{P}<0.001)$. Yield increase was shown at the level of $0.1 \%$ in the non-fertilised and the (A_120) treatment and at the level of $1 \%$ in the (V6_150) treatment.

In the dry year (2018), there was a significant yield decrease in comparison with the wet year (2016) in all treatments. This decrease was significant at the level of $0.1 \%$, except in the case of the (A_60) treatment, the decrease of which was not significant. The biggest yield difference was observed in the (V6_90) treatment.

In 2018, yield decreased in all treatments in comparison with 2017. The yield decrease was significant in the $\mathrm{A}_{120}\left(0.78 \mathrm{t} \mathrm{ha}^{-1}, \mathrm{P}<0.5\right)$ and the (V6_150) (1.77 t ha- $\left.{ }^{-1}, \mathrm{P}<0.01\right)$ treatment.

Summary: All three main factors (crop year, N fertilisation, phenophases) affected the relative chlorophyll content of maize at the level of $0.1 \%$, based 
on a multivariate ANOVA. Based on the MQ value, phenophase had the highest significance, followed by crop year and $\mathrm{N}$ fertilisation. The observed interactions were significant, except for crop year $\mathrm{x}$ fertilisation $(\mathrm{P}<0.001)$. The ANOVA performed for each year showed the modifying effect of different phenophases $(\mathrm{P}<0.001)$. However, based on the MQ value, $\mathrm{N}$ fertilisation had a primary role $(\mathrm{P}<0.01)$ in changing the relative chlorophyll content in the wet year (2016). The observed interaction (phenophase $\mathrm{x} \mathrm{N}$ fertilisation) was significant in each year. The level of significance was 5\% in 2016 and 2018 and $1 \%$ in 2017.

According to the multivariate ANOVA of the threeyear yield data, the effect of treatments (crop year, $\mathrm{N}$ fertilisation) on yield was significant at the level of $0.1 \%$. The effect of the interaction between crop year $\mathrm{x}$
$\mathrm{N}$ fertilisation showed a significant difference at the level of $5 \%$. The ANOVA performed for each year showed that $\mathrm{N}$ fertilisation was significant at the level of $0.1 \%$ in all three years.

\section{ACKNOWLEDGEMENT}

The research that this study is based on was supported by the Excellence Program of Higher Education Institutions on behalf of the Ministry of Human Resources, within the framework of the Theme 4 Program of the University of Debrecen. Furthermore, this publication was supported by the projects "Development of a scale-independent precision consultancy system - GINOP-2.2.1-15-2016-00001" and "EFOP-3.6.3-VEKOP-16-2017-00008".

\section{REFERENCES}

Árendás, T.-Bónis, P.-Micskei, Gy.-Sugár, E.-Szőke, Cs.-Marton, L. Cs.-Berzsenyi, Z. (2014): A kukorica termésreakciója és termésstabilitása N-trágyázási tartamkísérletekben. [In: Pepó P.Csajbók J. (szerk.) XIIII ${ }^{\text {th }}$ Congress of the European Society for Agronomy (ESA): Book of Abstracts]. Debrecen, University of Debrecen. 23-28.

Berzsenyi, Z.-Lap D. Q. (2003): N-mütrágyázás hatása a kukorica (Zea mays L.) hibridek szemtermésére és N-mütrágyareakciója tartamkísérletben. Növénytermelés. 52. 34-4: 389-408.

Berzsenyi, Z.-Lap, Q. D.-Micskei, Gy.-Takács, N. (2006): Effect of sowing date and $\mathrm{N}$ fertilization on grain yield and photosyntetic rates in maize (Zea mays L.) Cereal Research Communications. 34. 1: 409-412.

Bónis, P.-Árendás, T.-Jócsák, I.-Mikecz, Cs.-Micskei, Gy.-Marton, L. Cs. (2011): Effect of herbicides on the chlorophyll content of maize genotypes. [In: Veisz O. (szerk.) Climate Change: Challanges and Opportunities in Agriculture: AGRISAFE Final Conference]. Martonvásár, Agricultural Research Institute of the Hungarian Academy of Science. 143-146.

Csajbók, J. (2005): A tápanyagellátás és az asszimiláció közötti összefüggések kukoricánál. [In: Jávor A. (szerk.) Gyep, állat, vidék, kutatás, tudomány]. Debreceni Egyetem AGTC, Debrecen. 110-115.

Evans, J. R. (1989): Photosynthesis and nitrogen relationships in leaves of C3 plants. Oecologia. 78: 9-19.

FAOSTAT (2018): http://www.fao.org/faostat/en/\#data/QC

Graming, B. M.-Massey, R.-Do Yun, S. (2017): Nitrogen application decision-making under climate risk in the U.S. Corn Belt. Climate Risk Management. 15: 82-89.

Győri, Z. (2010): Corn: characteristics and quality requirements, [In: Wrigley, C. W.-Batey, I.L. (eds.) Cereal grains: Assessing and managing quality. Oxford, Cambridge: CRC Press Woodhead Publishing Limited, 183-211

HCSO (2018): http://www.ksh.hu/stadat

Islam, A.-Ahuja, L. R.-Garcia, L. A-Ma, L.-Saseendran, A. S.Trout, T. J. (2012): Modeling the impacts of climate change on irrigated corn production in the Central Great Plains. Agricultural Water Management. 110: 94-108.

Izsáki, Z. (2006): Effect of nitrogen supplies on protein content and amino acid composition in maize (Zea mays L.) kernels. Cereal Research Communications. 34. 1: 497-500.

Jolánkai, M.-Tarnawa, Á.-Horváth, Cs.-Nyárai, H. F.-Kassai, M. K. (2016): Impact of climatic factors on yield quantity and quality of grain crops. Időjárás/Quarterly Journal of The Hungarian Meteorological Service. 120. 1: 73-84.

Kesi, L.-Pawel, W. (2012): Corn production response to tillage and nitrogen application in dry-land environment. Soil and Tillage Research. 124: 138-143.

Marton, L. Cs.-Árendás, T.-Berzsenyi, Z. (2012): Martonvásári kukorica hibridek a szárazságban. Martonvásár. 24. 2: 4-7.

Micskei, Gy.-Berzsenyi, Z.-Árendás, T.-Fodor, N. (2014): Photosynthetic activity of maize (Zea mays L.) hybrids affected by nitrogen in a dry year. [In: Pepó P.- Csajbók J. (szerk.) XIII ${ }^{\text {th }}$ Congress of the European Society for Agronomy (ESA): Book of Abstracts]. Debrecen, University of Debrecen. 409-410.

Mukesh, D. B.-Silvia, S.-Justin, S. (2017): Projecting corn and soybeans yields under climate change in a Corn Belt watershed. Agricultural Systems. 152. C: 90-99.

Nagy, J. (2008): Maize production: Food, bioenergy, forage. Akadémiai Kiadó, Budapest.

Nagy, J. (2017): Klímaváltozás és a mütrágyázás hatása a kukorica termésére debreceni tartamkísérletben. Növénytermelés. 66. 3: $11-32$.

Nagy, J. (2018): Magyarország földhasználatának 150 éve (18682018). Növénytermelés. 67. 3: 51-72.

Niinemets, U.-Tenhunen, J. D. (1997): A model separating leaf structural and physiological effects on carbon gain along light gradients for the shade- tolerant species Acer saccharum. Plant, Cell and Enviroment. 20. 7: 845-866.

Noha, H.-Zang, Q. (2012): Shadow effect on multi-spectral image for detection of nitrogen deficiency in corn. Computers and Electronics in Agriculture. 83: 52-57.

Pepó, P. (2017): Tartamkísérletek mint a klímaváltozás indikátorai. Növénytermelés. 66. 3: 33-46.

Rasmus, H.-Martha, A.- Craig,- D. (2009): Utility of an imagebased canopy reflectance modeling tool for remote estimation of LAI and leaf chlorophyll content at the field scale. Remote Sensing of Environment. 113. 1: 259-274.

Sárvári, M.-Pepó, P. (2014): Effect of production factors on maize yield and yield stability. Cereal Research Communications. 42 . 4: 710-720.

Schepers, J. S.-Francis, D. D.-Vigil, M.-Below, F. E. (1992): Comparison of corn leaf nitrogen concentration and chlorophyll meter readings. Communications in Soil Science and Plant Analysis. 23: 2173-2187. 
Seyyed, M. S.-Seyyed, A. N.-Christos, A. D. (2018): Environmental sustainability of corn (Zea mays L.) production on the basis of nitrogen fertilizer application. Renewable and Sustainable Energy Reviews. 95: C: 48-55.

Soil Science Society of America. (2007): Growing Corn Using Precision Agriculture. ScienceDaily. ScienceDaily, 1 September.

www.sciencedaily.com/releases/2007/08/070831123423.htm

Széles, A.-Harsányi, E.-Kith, K.-Nagy, J. (2018b): The effect of fertilisation and weather extremities caused by climate change on maize (Zea mays L.) yield in Hungary. Journal of Agriculture Food and Development. 4: 1-9.

Széles, A.-Horváth, É.-Ferencsik, S. (2018a): A tavaszi nitrogén alap- és fejtrágyázás hatása a kukorica termésére és marginális jövedelemelemzése. Növénytermelés. 67. 3: 73-93.

Ványiné Széles, A. (2008): The effect of crop year and fetilization on the interaction between the SPAD value and yield of maize (Zea mays L.) within non-irrigated conditions. Cereal Research Communications. 36. 2: 1367-1371.
Ványiné Széles, A.-Megyes A.-Nagy, J (2012a): Irrigation and nitrogen effects on the leaf chlorophyll content and grain yield of maize in different crop years. Agricultural Water Management. 107: 133-144.

Ványiné Széles, A.-Nagy, J. (2012): Effect of nutrition and water supply on the yield and grain protein content of maize hybrids. Australian Journal of Crop Science. 6. 3: 381-290.

Ványiné Széles, A.-Tóth, B.-Nagy, J. (2012b): Effect of nitrogen doses on the chlorophyll concentration, yield and protein content of different genotype maize hybrids in Hungary. African Journal of Agricultural Research. 7. 16: 2546-2552.

Vig, R.-Dobos, A.-Molnár, K.-Nagy, J. (2010): Természetes alapanyagú lombtrágyák hatékonysága szabadföldi kísérletekben: I. Kukorica (Zea mays L.) Növénytermelés. 59. 4: 89-105. 
